\title{
Innovation in Public Service Delivery: Civic Participation in Slovakia
}

MERICKOVA, Beata M. | SVIDRONOVA, Maria M. | NEMEC, Juraj

\section{Abstract}

articipation as such is connected with
political, social and civic dimensions. Through participation, citizens can directly or indirectly help to make the public process become more transparent and more efficient. It allows citizens "to see" into a decision-making process, to understand it, as well as contribute and be able to control it. In practice, civic participation has various forms; it includes both formal civic associations and informal groups of citizens that develop activities in order to solve local problems. In this paper we focus on civic participation in the innovation in the provision of public services, i.e. co-creation. Our objective is to map the best practices of co-creation in social innovations at the local government level in Slovakia. The main findings of our analysis are that co-created innovations are mostly initiated by non-governmental actors. Our study uses a qualitative approach and is based on original survey data from our own research, conducted mainly within the LIPSE research project.

Keywords: Civic participation; Public services; Co-creation; Social innovations; Civil society.

\section{INTRODUCTION}

According to the Revised European Charter on the Participation of Young People in Local and Regional Life (2003), the active involvement of people in public life improves their identification with their hometown. Civic participation may take the form of various cultural events, improving the environment and club activities supported by the 
government etc. Citizens are not always interested in such contacts with their municipality and/or community. They lack a certain level of motivation. Most citizens understand by civic participation a very limited range of activities, e.g. participation in elections, social events, public meetings and also occasionally administration and decision-making on public affairs. In the paper, we will focus on public participation in relation to the provision of public services and the direct participation of citizens in initiatives that can help in innovating public services delivery. Public services are an important aspect that affects our daily lives, they are designed to meet the needs of public. The offer, range and accessibility of public services can lead to significant growth in the quality of life of citizens. Yet, a question arises, why do citizens participate so little in the innovation of public services?

Most definitions of innovation are known from the private sector, but the arrival of New Public Management (i.e. the introduction of market elements into the public administration) means increased implementation of new ideas and methods from the private sector to the public sector (Sibanda 2014). According to many authors (Cooper 2003; Wolak-Tuzimek \& Duda 2014; Nemec, Ochrana \& Šumpíková 2008; Kozuń Cieślak 2013; Pollit \& Bouckaert 2011; Lament 2012 and others) the marketization of the public services has several objectives, e.g. an increase in public expenditure efficiency, continual improvements in public services quality and the implementation of the professional management tools in the public sector, etc. For this paper an objective of the plurality system of ownership forms in public service delivering is important. This means approaches like 'public governance,' 'public-private-civil sector mix, partnerships, competition and cooperation,' and 'co-creation' (Cullis \& Jones 2009; Osborne \& Gaebler 1993; Nemec, Mikušová Meričková \& Svidroňová 2015). Co-creation is considered to be a social innovation in the production of public services. It opens the delivery process and involves the end users (citizens) in the design and development of goods and services (Chesbrough 2003; Silva \& Buček 2014; Von Hippel 2007). Co-creation is also considered to represent a change in the relationships between the involved stakeholders (Voorberg et al. 2014). One of the central elements in the concept of social innovation is the active participation of citizens and grassroots organizations in order to produce social outcomes that really matter (Bason 2010).

The objective is to map the best practices of co-creation in social innovations at the local government level in Slovakia. The research questions are as follows: 
1) What is the situation of co-creation in local public service delivery at the Slovak local self-government level?

2) What can we learn from the best practices of co-creation at the local government level in Slovakia?

Co-creation has become a focus of several current research projects, e.g. LIPSE (Learning from Innovation in Public Sector Environments) funded by the European Union. The LIPSE project methodology was also applied in this paper in order to analyse the ways of civic participation on the public services delivery, i.e. the co-creation. The methods are:

- Document analysis of relevant policy documents, databases and websites. To develop an inventory of relevant practices in which either citizens or many stakeholders are involved.

- Interviews with various experts on co-creation processes during public innovation. This is used to develop and verify the inventory of best practices.

\section{THEORETICAL FRAMEWORK}

According to Piller, Ihl and Vossen (2010), the active participation of citizens is a creative and social process based on collaboration between producers (in our case the local government) and users (citizens). Nambisan and Nambisan (2013) argue that civic participation is an act of involving end-users directly, in some cases repeatedly, in creating products or in the innovation processes.

Civic participation is a concept that was brought to Slovakia in the early nineties from Western culture. However, that does not mean that participation of the public in the decision-making did not previously exist in the country. On the contrary, public participation has a long tradition in Slovakia, but it was referred to by other terms such as co-decision. This tradition was interrupted after the Second World War when the Communist Party came to power and any civic activities whatsoever were suppressed (Pirošík 2005). Tradition, together with state governance, is one of four factors that influence the context of civic participation and innovation, the other three are: 1) the political and administrative context, 2) the legal culture within the public sector, 3) resource allocation and resource dependency (Voorberg et al., 2014). 
Participation of citizens in the development and subsequent implementation of an innovation (co-creation) is of great importance in terms of the success of the public service innovation process because they are the end consumers of the public service (Von Hippel 2007).

In the private sector there is a rich history of companies partnering with customers or product/service users in innovation and value creation (ibid). Across industries (and particularly in the technology and consumer sectors), customers have played a key role in suggesting improvements and new features for existing products and services. For example, companies such as Hallmark, Lego, BMW, Ducati, and Procter \& Gamble have all taken ideas and suggestions from customers to improve their products (Nambisan, Nambisan 2013). Certain types of user, referred to as lead users, have undertaken a more active role in innovation, often designing or developing a new or derivative product. For example, many skateboarding, windsurfing, and snowboarding equipment innovations have come from modifications made by sports enthusiasts to their own equipment over time. Other lead users have innovated completely new products to meet a need for which no product existed (Von Hippel 2007).

The role of citizens in public service innovation has a less well-known, albeit equally rich history. Many social innovations (e.g., the environmental movement and Earth Day) originated from ideas and suggestions offered by individuals outside government. Often, it has taken a group of citizens or community-based movements to spur government agencies to act on such ideas. What has changed in recent years is the ability of individual citizens to not only develop innovative solutions to problems, but to play a more active role in discovering or identifying the root problems and in developing and/or implementing solutions. A large part of this can be attributed to new technologies that facilitate easier access to public data, enhance government transparency, and reduce the gap between the citizen innovator and the government agency (Nambisan, Nambisan 2013).

Based on studies from various authors, there are several roles of citizens participating in co-creation. This may refer to citizens as value creators (Briscoe, Keränen \& Parry 2012), citizens as collaborative partners (Baumer, Sueyoshi, \& Tomlinson 2011), or to the role of citizens as active agents in public service delivery (Gebauer, Johnson, \& Enquist 2010). From this variety of definitions and the conceptual confusion with related 
concepts, Voorberg et al. (2014) concluded the type of relationship between citizens and public organizations and distinguished three different ideal-types of citizen participation:

1) Citizens as co-implementer. citizen involvement in which citizens carry out public service tasks which in the past were carried out by public organizations.

2) Citizens as co-designer. citizens determine to a large extent how services are being designed and implemented.

3) Citizens as initiator: citizens take the initiative for public service delivery and public institutions are invited to join.

Nambisan, S. and Nambisan, P. (2013) added a fourth type of role for citizen in cocreation, the so-called explorer. In their opinion, citizens as in the explorer role reflect the citizens' ability to discover or identify problems that are either invisible or unknown to government agencies. It also involves articulating problems in ways that would lead to practical solutions. It is widely accepted that citizens, being "closest to the ground," are likely to be aware of current or emerging civic problems well before their (local or regional) government is.

A wide range of mechanisms can be employed by government agencies to facilitate the four citizen roles in innovation and problem-solving. These include mobile apps, epetitions, open-source databases, data analysis communities, contests and competitions, innovation jams, open databases, participatory design workshops, and dedicated online citizen communities. While these mechanisms form the practical ways for government agencies to engage with citizens in different aspects of problem-solving, two themes or elements of co-creation underlie them (Lusch \& Nambisan 2015):

- Innovation ecosystem - offers an organizing structure for an ensemble of actors (citizens, government employees, non-profits, etc.) to come together and cocreate service offerings.

- Innovation platform - provides a venue (physical or virtual) for innovation and problem-solving.

The influential factors that play a vital role in civic participation can be described as follows:

1) Willingness of citizens: Individual citizen characteristics: what induces clients to get involved is relying to a large extent on the willingness of citizens to co- 
create (Ajzen 1991). Intrinsic motivation can increase this willingness of citizens to co-create. This intrinsic motivation is determined by their conviction of the need for co-creation (Pestoff 2012). Individual characteristics seem to be influential in this intrinsic motivation. For instance, Wise et al. (2012) described that in order to understand why citizens participate, one should take into consideration to what order citizens feel compelled to fulfil their 'civic duty' and are willing to contribute to 'a greater good'. Furthermore, it appears that personal characteristics influence this awareness of a civic duty and the willingness to contribute. In general, higher educated women with children are the most willing to co-create (Voorberg et al. 2014). It also seems that citizens from a medium-sized municipality (50,000-90,000 inhabitants) are more willing to co-create than citizens from smaller or larger communities (ibid). Other external factors seem to influence this willingness as well. For instance, Weinberger \& Jutting (2001) describe the weight of participation costs in the consideration of citizens to participate.

2) Citizen awareness of actual influence and ownership: citizens should also be able to see the possibility of influencing public service delivery. Pestoff (2012) concluded from his international comparison to preschool services that participation of parents actually breeds participation. Parents talk to each other and enthuse their fellow service users. The importance of awareness is also mentioned by Gebauer, Johnson \& Enquist (2010). They concluded that once customers of the Swiss railway-services had the feeling that they could actually participate and increase the quality of the services, this not only resulted in a 'snowball' effect, but people also had the feeling that they were responsible for the quality of the railway services. Hence, when people feel they can actually influence public services, this may result in more feelings of 'ownership.'

3) Social capital: social capital can positively influence co-creation efforts of citizens. It is not always clear what is meant by the term 'social capital'. For instance, Andrews \& Brewer (2012) approached the concept quite 'technically,' referring to the number of social organizations per capita or the average income per capita. Most of the time, social capital refers to the number of alliances between individuals in a specific city or neighbourhood (Voorberg et 
al. 2014). Following this line of reasoning, we understand social capital as the extent to which actors possess network relations with other actors. However, the quality of these social relations is determined by the level of trust citizens have with each other and the engagement of said citizens (ibid). Some authors have mentioned that a reason for participation is an urge 'to belong to something' (e.g. Van Dijck \& Nieborg 2009).

Connecting civic participation, co-creation and innovation, we must state that Slovakia ranks $24^{\text {th }}$ out of 39 evaluated countries in Europe by Global Innovation Index (2015). The Global Innovation Index was introduced as part of the Lisbon Strategy and represents an annual assessment of each country in terms of their performance in innovation policy. Co-creation with active participation of citizens might be a tool in how to improve the innovation index for Slovakia.

If an introduction of innovation leads to a significant improvement and is useful in several areas, it becomes a best practice. It is a practice, which based on experience and research, leads to the best results from among all the possible alternatives. Best practices should have the following characteristics:

- have a proven impact on improving the quality of life of citizens,

- are the result of effective partnerships between the public and private sectors and civil society,

- are sustainable from social, economic and environmental terms (Staroňová et al. 2012).

We therefore present selected best practices of co-creation in the following section and thus we answer the first research question.

\section{BEST PRACTICES OF CIVIC PARTICIPATION}

As we want to analyse co-creation in public service innovation processes, we should therefore focus on co-creation practices where citizens are involved as co-designer and/or initiator, i.e. their participation is rather active. We followed three main selection criteria when identifying eligible cases:

- Citizens involved as co-designer or initiator. From the systematic review of cocreation and co-production within the public sector, we concluded that in the 
Innovation in Public Service: Civic Participation in Slovakia 271

literature on co-creation/co-production three different types of citizen involvement can be distinguished: 1) citizens as co-implementer, 2) citizens as co-designer and 3) citizens as initiator. Since we are interested in co-creation during social innovation processes we focus our research on the involvement of citizens as initiator and as co-designer. This implies that within the selected cases citizens were involved at least at the start of the co-creation initiative.

- Cases from policy sectors public welfare, rural/urban regeneration, social services and education: We conducted our research within these four policy domains.

- Possible to specify the outcomes of co-creation processes. As our systematic review has revealed, it is relatively unknown what kind of outcomes co-creation processes have in social innovation. In order to draw some conclusions about these outcomes, it is implied that selected cases should involve co-creation initiatives which are not in the starting phase any longer but have already delivered (some) results.

The list of best practices suggests that there are several interesting co-creation innovation initiatives in Slovakia at local government level.

\section{"Photo traps" in Bratislava}

This co-creation initiative was initiated by the civic association Green Patrol (Zelená hliadka), which has been highlighting the problems of waste on the streets of the capitol Bratislava since 2011. Its aim is to motivate citizens to start being more considerate towards environmental protection and the problems of waste accumulating in the area where they live. The Green Patrol also campaigns the issue that the local government is only marginally interested in the removal of illegal dumps and cleaning up of public areas and invests extremely little funding in these rather important activities.

Within the project, the members of the civic association focused on cleaning up five illegal dumps in the period September 2013 - January 2014. In order to keep these places clean, i.e. to prevent any new pollution, photo traps were installed there. The idea of the photo traps is that images are taken when somebody dumps any waste on these places and are immediately sent to the mobile phones and e-mail addresses of Green Patrol members, and thus these offenses are reported to the police in quick time. 
The project aimed at cleaning up those public spaces that have been polluted for many years. The cleaned up places where photo traps have been installed report positive results regarding the minimum of pollution or even revealing the waste dumpers. In the initiative, citizens grouped in a civic association came up with the idea, a private company Orange provided information and communication technologies and the city of Bratislava provided some funding; most of the work was done voluntarily.

\section{Support of Education Program - let's go further!}

Children from socially excluded Roma localities (so-called slum settlements) face many problems during their school attendance. From low preparedness for school combined with insufficient support from their parents during school attendance to a weak readiness of the schools to meet the educational needs of children result in them falling through the cracks of the education system from the first grade onwards. The inability of the children to meet the requirements of schools and insufficient learning achievements often result in repetition of school years or moving the children into special schools and classes for the mentally challenged. For Roma children from the slum settlements their education process often ends upon completion of compulsory school attendance. These facts nowadays predetermine the further life path of Roma children; a generation of young people without any real education or a real chance to be included in the labour market and wider society.

The main objective of the Support of Education Program, operated by the NGO People in Need - Slovakia, is to improve the educational attainment of Roma children and youth and thereby to improve the possibilities for future access to employment and inclusion into society in general. The program focuses on two main barriers to access education - the barrier on the side of the family and that on the side of schools and the school system as a whole. There is the low stimulation of the social environment in which the children grow up, the unsatisfactory home background for preparing for school, the low education level of the parents and their often insufficient ability to help their own children with preparing for school, all of which lead to the children not being able to keep up with their peers or to meet the requirements of school. On the other hand, the social disadvantages of children at the beginning of and during school attendance are combined with the low ability of schools to adequately react to the educational needs of the children. Many pedagogues are resigned to expect a minimum 
performance from Roma pupils which has the downside that it has a negative influence on the children's motivation. Due to the absence of training in the field of inclusion methods they often do not possess the skills needed to adapt education in such a way as to be able to meet the individual needs of such children.

The Support of Education Program aims to support Roma children on their entire education path until they finish secondary (possibly university) education as well as offering assistance to the schools. The preschool clubs aim to prepare children for admission to a regular primary school. The intention of the individual tutoring program is to improve children's results at primary school and prepare them for entrance exams to secondary schools. The increase in the number of children that continue with their education to secondary school is the objective of the career counselling program and individual scholarship. Through teacher training and methodological guidance of schools, the program also aims to improve the primary school environment so that it becomes more inclusive and prepared to meet children's educational needs.

In this co-creation initiative, the funding is provided by EEA Grants (Fund for Active Citizenship and Inclusion Program), several municipalities from the east of Slovakia are cooperating. According to the first results of the program it meets its aim to motivate youths to continue their education - all participants of the program submitted their application for secondary school. Educational services for clients are provided by the involvement of a large number of volunteers (more than 30) who also have the opportunity to improve their professional competence during specialized training and seminars (since the beginning of the project 5 seminars have been held). Furthermore, close cooperation with two primary schools has been established and more than 20 teachers have participated in excursions and training all aimed at a pro-inclusive approach and educational methods.

\section{Project ViTo}

ViTo is the abbreviated name for a European cooperation project aimed at the revitalization of historic city centres in Europe. The entire project title is: "Integrated Urban Development of Vital Historic Towns as Regional Centres in South East Europe". The project was financed by the European Regional Development Fund. The lead partner of the project was the Slovenian town of Ptuj, in Slovakia the project was implemented 
in the town of Banska Stiavnica. The duration of the project was from August 2009 August 2012.

For designing integrated and sustainable development planning in historic municipalities, the project focused on the use of public participation. To achieve the revitalization of the historic centre of the town/city, the local government had to work closely with citizens, companies and other stakeholders. If the municipality made decisions by itself, the citizens could have had a negative attitude towards implemented changes in the rural area. The process of public participation in policy-making ensured that the resulting plan of municipality development would be balanced, supported and adopted by citizens, which was also an important foundation for its successful implementation. In a case of town centre revitalization, which is a specific area where many people live, operate or visit it because of recreation and great cultural and tourist attractions, the use of public participation in policy-making is very logical and appropriate. From an economic point of view, thanks to tourism the historical centre becomes an important source of revenue for the municipality and its citizens. It is therefore necessary for the town to involve all stakeholders, interested groups and individuals in decision-making processes.

The town of Banská Stiavnica organized five public meetings in the first half of 2011. These were the four public meetings called Brainstorming workshops with the topic of revitalization of the historical centre of Banska Stiavnica. The public learnt about these meetings during the initial "kick-off" public meeting organized by the town at the beginning of 2011. The results of the meetings were further used in the project by carrying out pilot projects and the inclusion of the shared vision of the town's development plan. In the public meetings 103 citizens in total took part.

The project aroused interest among many people who were interested in the development of the historical centre of Banska Stiavnica. The meeting was attended by active citizens, representatives of the business sector (including tourism), government organizations (the Slovak Mining Museum and the local Labour office), social services organizations (retirement homes and the Red Cross); there were also many participants from various local non-governmental organizations and civic associations. The town was represented by the Mayor, the Deputy Mayor and other employees (heads of departments of the town hall) and members of the City Council. Public meetings and the project as such, achieved a broad and diverse range of participants (Figure 1). 
Figure 1 Overview of public meetings attendants

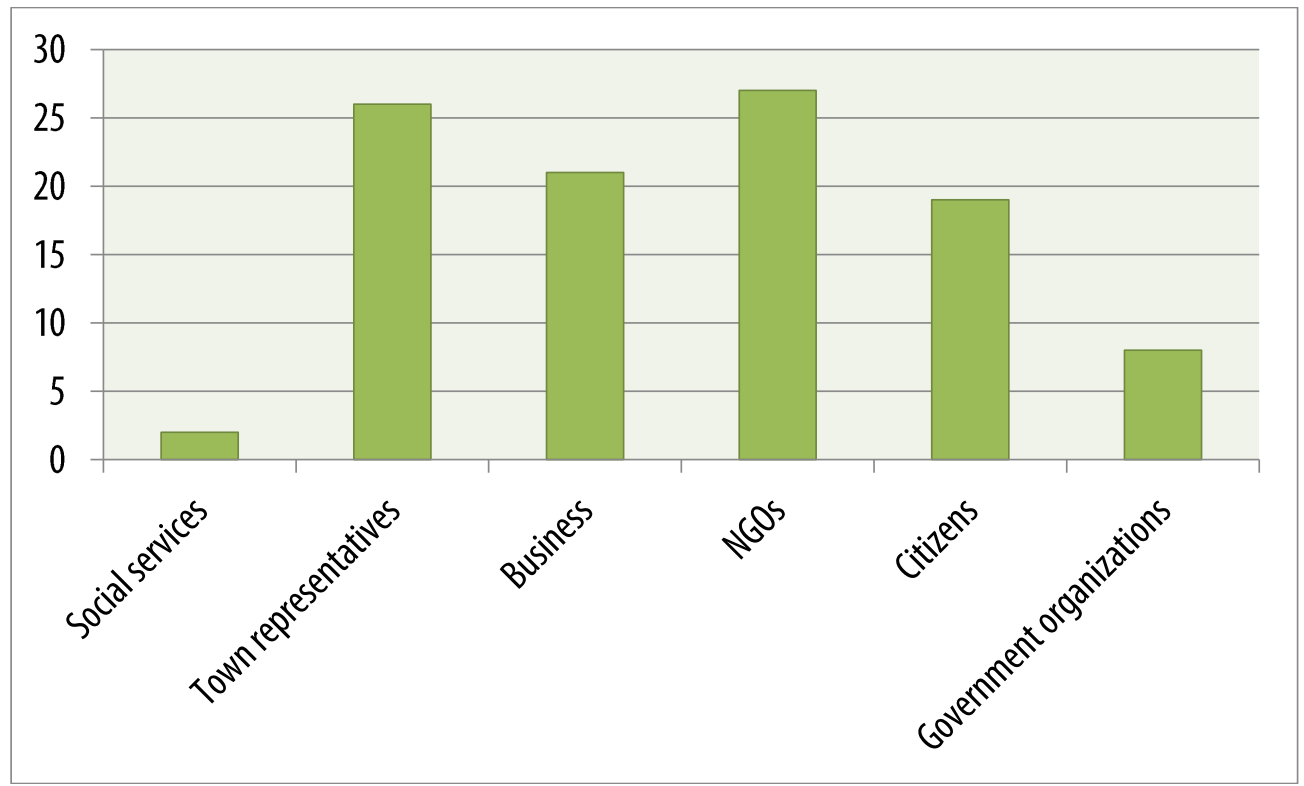

Source: authors

\section{The Theatre of the Oppressed}

Living as a homeless person, besides the physical inconvenience, means mental discomfort. Weeks, months, even years of just roaming the streets with no perspective and clear future leads to a deterioration of personality, mental emptiness and very often leads to alcohol addiction. This is a general problem of many cities and there are not many known solutions of how to get out of this state. One of a few tools how to get homeless people out of this downward slide and improve their life is their participation in theatre. Dramatic art and acting bring self-fulfilment and a reason for living to homeless people; it allows them to show that they are normal people who are not only worthy of our attention but are able to bring many benefits to the public.

The Theatre without a Home (Divadlo bez domova) in Bratislava brings such a chance to homeless people. It was established in 2005 with two main goals: to provide the homeless and socially excluded people with the chance to fill their lives and give them the opportunity to communicate their situation, to socially display themes ignored by "regular" arts. Naturally, the main activity of the theatre is rehearsing and performing the 
plays. Actors rehearse every week; many of them are physically handicapped with the support from the assistants. They perform the plays mostly in Bratislava on their home stage in Pisztory's Pallace, which is rented from the city administration. However, they have also performed in other towns around Slovakia on various occasions, from individual plays to festivals, celebrations, etc.

The co-created project is called "The Theatre of the Oppressed." It is also the name of a specific method used in social theatre, introduced by director Augusto Boal who used this approach in the slums of Argentina. The method involves the audience in the play, allowing them to directly react to various problems and questions communicated by the actors - the poor and socially excluded people. Patrik Krebs, director of the Theatre without a Home, came up with the idea that the problems of poor people from Argentinean slums are very similar to those of the homeless and socially excluded people in Bratislava. So, he decided to adjust the method to Slovak circumstances and to rehearse and introduce a new play, using the theatre of the oppressed approach. The theme of the play is the verbal and physical attacks by the public on the homeless on the streets. The audience try to empathize with homeless people and experience their day-to-day life. In addition, rehearsals and performances are "artwork" therapy for the homeless and socially excluded people which increases their resistance to problems and improves the quality of their hard life.

\section{Creating a network of attractive historical parks - the town of Rusovce}

In the context of cross-border cooperation project "Creating a network of attractive historical parks" a guided participation process was carried out from November 2003 to November 2004 in the town of Rusovce. The aim was to mobilize the local community so as to cooperate in creating a vision of the rare historical park in Rusovce and to strengthen the capacity of local people for further cooperation. Not only the citizens of Rusovce but also local authorities and civic associations had the opportunity to participate in the creation and revitalization of the local park through a series of activities and try out how it is to decide in public affairs. Within a few months, out of a total number of 2,000 residents, inputs were received from 400 people. Numerous workshops, a concert, a poll, a public hearing, a planning weekend, a cross-border seminar and public presentation of the study for revitalization with incorporated 
suggestions from citizens were realized. Even children from a local school participated by creating booklets about the park.

The project achieved its objectives; in addition to involvement in the planning and getting the initial experience with participation, a broader group of active people was also formed. This group includes local entrepreneurs, students and people working in culture, all willing to work further on the revitalization of the park. The cooperation of local government with active citizens who initiated the establishment and provision of public services was a very good way of communication between the municipality and the citizens themselves. It is up to the municipal authorities to best understand and take into account the views and attitudes of citizens' initiative. It is the active citizens that tend to participate in improving the lives of the community and thus help in the development the municipality.

\section{CONCIUSION}

Participation and active citizenship is about having the right, the means, the space and the opportunity to participate, to influence decisions and engage in actions and activities as well as contribute to building a better society. Civic participation in Slovakia has clearly established itself, thereby becoming an effective instrument of innovation in the more efficient and transparent delivery of public services; it is necessary to identify what stimulates this. Based on the presented best practices we can identify several drivers for civic participation. The first condition that must be met is the identification of joint interest of citizens and local government.

An innovative approach to public services is essential for their development and simplifying and improving the quality of their delivery. Not only local governments, but also citizens must expend an effort and come up with initiatives in providing public services through projects that improve the quality of life and the environment. From all the presented cases it is clear and undeniable that a group of people have a rather significant impact on their surroundings and community/municipality development. Therefore, individuals with the same interests and objectives are often organized into civic associations and communities with the intention of various interest programs, funded by foreign and domestic foundations (Kuvíková \& Vaceková, 2009; Michalski \& Mercik, 2011). Many of these interest groups came into being precisely because of this lack of funding from local government or due to the passivity of local government in 
solving the different problems of the citizens. In Slovakia this can be the way for a wider spreading of the co-creation and civic participation.

In this paper we presented five examples of co-creation based innovations at the local government level in the four selected fields of welfare, environment, social services and education in Slovakia. On the basis of our analysis of the investigated cases we can state that the role of local government in co-creation in Slovakia is rather limited. Our opinion is that the main problem and reason for this lies in the traditions and type of governance inherited from the previous socialist history of Slovakia and cannot be treated immediately. In Slovakia social innovation comes predominantly from third party organizations or the citizens themselves, i.e. the civic participation plays a vital role in the innovation in public services delivery. If the local government is an initiator of a social innovation, it is usually thanks to funding from the European Union (the presented cases of Banska Stiavnica and Rusovce). On the other hand, in these two cases, the willingness of the citizens to participate was enormous; also the social capital was utilized to the maximum by involving various stakeholders. By participating on the revitalization of urban spaces the feeling of ownership increases, i.e. the citizens feel the public spaces to be their own and thus protect them from vandalism.

Another interesting point shown in our research was that several innovations in public services delivery are based on the use of information and communication technologies (ICT); in our case the Photo traps project. The potential for innovations based on ICT is determined by the politico-social environment. Information and communication technologies may contribute significantly to the fulfilment of one of the key conditions for successful implementation of innovations to the system of public services, and to the direct participation of citizens as consumers of public services in the service innovation process. The ICT driven innovations in public services may therefore be an incentive or driver for social innovations and civic participation in Slovakia and as such we will focus our future research on this link between ICT and social innovations at local government level. We would also want to focus on researching the potential of non-governmental organizations for social innovations. 
Innovation in Public Service: Civic Participation in Slovakia 279

\section{ACKNOWLEDGEMENT}

This research is supported by the LIPSE project. LIPSE or "Learning from Innovation in Public Sector Environments" is a research project studying the drivers and barriers of successful social innovation in the public sector. With a budget of 2.5 Million Euros funded by the 7th Framework Programme of the European Union - it is one of the largest projects on social innovation in the public sector. The research is being conducted by EU researchers from 12 different universities in 11 countries. The project started on 1 Feb. 2013 and will run for 3.,5 years. It is coordinated by prof. Victor Bekkers and Dr. Lars Tummers from the Erasmus University Rotterdam. The research is co-financed at local level by the APVV project DO7RP-0010-12.

\section{List of References}

- Ajzen, I 1991, "The theory of planned behavior", Organizational behavior and human decision processes, vol. 50, no. 2, pp. 179-211.

- Andrews, R \& Brewer, GA 2013, "Social capital, management capacity and public service performance: Evidence from the US states", Public Management Review, vol. 15, no. 1, pp. $19-42$.

- Bason, C 2010, Leading public sector innovation, Bristol: Policy Press.

- Baumer, EPS, Sueyoshi, M \& Tomlinson, B 2011, "Bloggers and readers blogging together: Collaborative co-creation of political blogs", Computer Supported Cooperative Work, vol. 20, no. $1-2$, pp. 1-36.

- Briscoe, G, Keränen, K \& Parry, G 2012 "Understanding complex service systems through different lenses: An overview", European Management Journal, vol. 30, no. 5, pp. 418-426.

- Chesbrough, HW 2003, "The era of open innovation", MIT Sloan Management Review, vol. 44 , no. 3 , pp. $35-42$.

- Cooper, PJ 2003, Governing by contract: Challenges and opportunities for public managers, Washington, DC: CQ Press.

- Cullis, J \& Jones, P 1987, Public sector economics, Oxford: Blackwell Publishing. 
- Gebauer, H, Johnson, M \& Enquist, B 2010, "Value co-creation as a determinant of success in public transport services: A study of the Swiss Federal Railway operator (SBB)," Managing Service Quality: An International Journal, vol. 20, no. 6, pp. 511-530.

- Global Innovation Index 2015, Available from: https://www.globalinnovationindex.org/content/page/data-analysis/

- Jankovič, M. 2014, Realizácia projektu bylinné trávniky. Available from: <http://pr.banm.sk/liferay/financovanie_bs> [12 December 2015]

- Kozuń - Cieślak, G. 2013. "Ocena efektywności inwestycji publicznych w kapitał ludzki," Ekonomista no. 3, pp. 319 - 344.

- Kuvíková, H \& Vaceková, G 2009, "Diverzifikácia finančných zdrojov v neziskových organizáciách", E+M Ekonomie a management, vol. 12, no. 4, pp. 84-95.

- Lament, M. 2012, "Wartość godziwa jako kategoria wyceny w zakładach ubezpieczeń", in Management of organization in real and virtual environment: opportunities and challenges $I V$, ed. L Lesakova, Univerzita Mateja Bela v Banskej Bystrici, pp. 1-9.

- Leading cities, 2012. Applying Business Practice to the Public Sector: Co-creating cities Defining co-creation as a means of citizen engagement. Available from: < http://leadingcities2014.files.wordpress.com/2014/02/co-creation-formatted-draft-6.pdf > [28 November 2015].

- Lusch, R \& Nambisan, S 2015, "Service Innovation: A Service-Dominant Logic Perspective", MIS Quarterly, vol. 39, no. 1, pp.155-175. [28 November 2015].

- Michalski, G \& Mercik A 2011, "Liquid assets strategies in Silesian non-profit organizations." Financial Management of Firms and Financial Institutions, pp. 258-270.

- Nambisan, S \& Nambisan, J 2013, Engaging Citizens in Co-Creation in Public Services (Lessons Learned and Best Practices). IBM Center for Business of Government. 2013.

- Nemec, J, Mikušová Meričková, B, Svidroňová, M 2015, "Co-creation in local public services delivery innovation: Slovak experience," Lex localis - Journal of Local Self-Government, vol. 13, no. 3, pp. 521-535.

- Občianske združenie Zelená hliadka. Available from: <http://zelenahliadka.sk/projekty/> [1 December 2015].

- Osborne, D \& Gaebler T 1993, Reinventing government: How the entrepreneurial spirit is transforming the public sector. Available from: 
<http://government.cce.cornell.edu/doc/summary.asp?id=osborne1992\#market> [28 November 2015].

- Pestoff, V 2012, "Citizens and co-production of welfare services: Childcare in eight European countries", Public Management Review, vol. 8, no. 4, pp. 503-519.

- $\quad$ Piller, FT, Ihl, C, \& Vossen, A 2010, "A typology of customer co-creation in the innovation process", available at SSRN 1732127.

- Pirošík, V 2005, Participácia v samospráve (Nástroj protikorupčnej politiky), Transparency International Slovensko, Bratislava. ISBN 80-89041-87-6.

- Pollit, CH \& Bouckaert, G 2011, Public Management Reform: A Comparative Analysis new public management, governance, and the neo-weberian state, Third Edition Oxford, Oxford University Press.

- Revised European Charter on the Participation of Young People in Local and Regional Life, 2003. Available from:

<https://www.coe.int/t/dg4/youth/Source/Coe_youth/Participation/COE_charter_participatio n_en.pdf> [1 December 2015].

- Sibanda, MMM 2014, "Monitoring customer-focused quality service delivery in Local government: conceptual issues and perspectives for consideration", Africa's Public Service Delivery and Performance Review, vol. 1, no. 12014.

- Silva, CN \& Buček, J 2014, Fiscal Austerity and Innovation in Local Governance in Europe, Surrey: Ashgate.

- Staroňová, K. et al. 2012, Inovácie vo verejnom sektore Slovenska - prípadové śtúdie, Centrum excelentnosti pre spoločenské inovácie UK, Bratislava. ISBN 978-80-223-2997-5.

- Šumpíková, M, Nemec, J \& Ochrana, F 2008, "Czech and Slovak lessons for public administration performance evaluation, management and finance", Ekonomický časopis, no. 04 , pp. 353-369.

- Van Dijck, J \& Nieborg, D 2009, "Wikinomics and its discontents: a critical analysis of Web 2.0 business manifestos." New media \& society, vol. 11, no. 5, pp- 55-874.

- Von Hippel, E 2007, "Horizontal innovation networks - by and for users", Industrial and Corporate Change, vol. 16, no. 2, pp. 1-23.

- Voorberg, WH, Bekkers, VJJM \& Tummers, LG 2014, "A systematic review of co-creation and co-production: Embarking on the social innovation journey." Public Management Review ahead-of-print, pp. 1-25. 
- Weinberger, K \& Jütting, JP 2001, "Women's participation in local organizations: conditions and constraints", World Development, vol. 29, no. 8, pp.1391-1404.

- Wise, S, Paton, RA, \& Gegenhuber, T 2012, "Value co-creation through collective intelligence in the public sector: A review of US and European initiatives", Vine, vol. 42, no. 2, pp. 251-276.

- Wolak-Tuzimek, A \& Duda, J 2014, "Innovation as a factor of competitiveness of small and medium-sized enterprises," Ad A/ta: Journal of Interdisciplinary Research, vol., no. 2.

\section{AUTHORS' CONTACT:}

\begin{tabular}{|c|c|c|}
\hline $\begin{array}{r}\text { Merickova, B.M. } \\
\text { Professor, } \\
\text { Faculty of Economics } \\
\text { Matej Bel University Banska } \\
\text { Bystrica, Slovakia } \\
\text { Email: } \\
\text { beata.mikusovamerickova@umb.sk }\end{array}$ & $\begin{array}{l}\text { Svidronova, M.M. } \\
\text { Asst. Professor } \\
\text { Faculty of Economics } \\
\text { Matej Bel University Banska } \\
\text { Bystrica, Slovakia } \\
\text { Email: } \\
\text { maria.murraysvidronova@umb.sk }\end{array}$ & $\begin{array}{l}\text { NEMEC, Juraj } \\
\text { Professor, } \\
\text { Faculty of Economics \& Admin } \\
\text { Masaryk University, } \\
\text { Lipová 41a, } 60200 \text { Brno, } \\
\text { Czech Republic } \\
\text { Email: juraj.nemec@umb.sk }\end{array}$ \\
\hline
\end{tabular}

